\section{Ethical Lingua}

Journal of Language Teaching and Literature

ISSN 2355-3448 (Print)

ISSN 2540-9190 (Online)

Volume 5, Number 1, February 2018

pp. $1-15$

\title{
Politeness Indicators in Nigeria Legislative Discourse
}

\author{
Clara Unoalegie Bola Agbara \\ bolegie@gmail.com \\ Nile University of Nigeria, Abuja, NCT, Nigeria \\ Received : 12 October 2017; Accepted: 04 December 2017 \\ DOI : : https://doi.org/10.30605/ethicallingua.v5i1.679
}

\begin{abstract}
In every human interaction, interlocutors strive to maintain appropriate decorum and politeness in order to avoid undue feeling of not being 'nice' or being insensitive to co-participant's self-esteem or image. This culture of being 'nice' is expressed not only through verbal codes, but also through non-verbal cues such as pitch, tone, voice modulation, facial expression and other forms of body language. Nigeria legislative House reflects the uniqueness of Nigeria as a multicultural nation with about two hundred and fifty ethnic groups. Each tribe has a unique way of expressing 'nice' (politeness). This paper examines how Nigerian legislators from different ethnic groups acknowledge the self-esteem of other legislators during senate debates. The study used Scollon and Scollon's politeness principle which states that in every interaction there is a continuous 'face' (self-image) negotiation and this 'face' which is made up of two aspects - involvement and independent- must be balanced during interactions because 'face' is a paradoxical concept. The interest of this study is to identify and to explain how politicians, who though are in opposition, acknowledge the self-esteem of others. Six hansards were sampled from 2009 to 2010, one bill from each quarter of the year. It was discovered that speakers almost always punctuate their contributions to debate with different types of politeness indicators as a means of acknowledging both the involvement and dependent face wants of participants. The politeness indicators often used by senators include address forms which are used not only as vocative (to the presiding senator) but also as designative (for reference to a third person mentioned in the speech), first person plural pronouns, rhetorical (speech) politeness markers and ritualized utterances.
\end{abstract}

Keywords:politeness indicators; face-wants; linguistic codes; pragmatics; communicative acts 


\section{Introduction}

In most communicative events, participants are often careful in their choice of dictions. They habitually shun to make co-participants/addressees feel that their 'face- wants' are being disregarded or rubbished. This courteousness or acknowledgment of the 'face-want' of the other person is expressed not only through choice of linguistic codes, but also through the speaker's non-verbal expressions such as pitch, tone, voice modulation, facial expression and other forms of body language. Respecting the 'face-want' of participants in any interaction is a necessary strategy for achieving effective and efficient communication irrespective of the nature of the communicative event.

Like every other communicative situation, participants in legislative interaction use their communicative behavior to express varied judgments and interests which sometimes may contradict the beliefs and interests of other participants who belong to different political party and ideology. Consequently, legislative interaction is characterized by opposing ideas, views and interests and hence, it can be regarded as a sub-genre of argumentative discourse. Argumentative discourse is characterized by series of disagreement terminologies which make the discourse 'conflict' prone environment. However, in such conflicting and opposing situation, participants in the communicative situation ensure that co-participants are not 'hurt' by their utterances.

\section{Pragmatic Study}

The origin of pragmatics as an independent subfield of linguistic developed in the 1970s. However, the term 'pragmatics' was first used by Charles Morris in his work Foundations of the Theory of Signs (1938), as a division of semiotics when he identified three distinct branches of semiotics; namely, syntactic (or syntax), semantics and pragmatics. He described pragmatics as the study of "the relation of signs to interpreters" (qtd. in Levinson p. I). Modern pragmatics still toil the line of Charles Morris' notion though in a more extensive form. Therefore, pragmatic study deals with how speakers express their intentions through their choice of words. It examines different 'properties and processes' of language usage as well as the meaning of the structures and forms of the utterances/sentences as constrained by the context of usage. It scrutinizes how speakers express their intentions or messages as encoded in the configuration and form of the utterance/sentence of the speaker, in addition to the speaker's expressed non-verbal clues. Pragmatics has been able to demonstrate that speaker meaning is distinct from sentence meaning. Speaker meaning, which can be performed explicitly or implicitly, refers to the speaker's intention or the message being communicated through the choice of words while sentence meaning, which is the surface meaning, refers to the traditional function assigned to different sentence form. Traditionally, declarative sentence function 
as information provider, imperative sentence as command giver or request maker, and interrogative sentence as information seeker.

Pragmatics has shown that speakers can decide to deviate from these traditional functions of sentence type in order to express speaker peculiar meaning which is context dependent. Thus pragmatics deals with the language options available to users and the implications of such options on the addressee. Pragmatic study is a case of 'a shift from the paradigm of theoretical grammar to the paradigm of language user' (Mey, 2001, p. 4). Its major interest lies in how participants in any communicative environment are able to produce and comprehend communicative acts based on their contextual knowledge, common ground and other sociolinguistic features.

One major interest of pragmatic study is politeness phenomenon in communicative situation. According to Grundy, politeness phenomena are "paradigm example of pragmatic usage" (2000, p.146). Politeness implies etiquette or appropriate behavior and most researchers agree that the goal of politeness is to create 'conducive' atmosphere for interaction. Holmes sees it as "an expression of concern for the feeling of others" (4). It is "showing awareness of and consideration for another person's face" (Yule, 2008, p. 119). Grundy (2000) commenting on past works on politeness phenomena observes that Lakoff (1973) considers politeness principles as having a wide descriptive power with regards to language use; and Leech (1983) feels it is the "major determinants of linguistic behavior" (p. 144). Grundy (2000, p. 140), on his part, views it as the "manifestation of the wider concept of etiquette, or appropriate behavior." Thus, politeness is exercised through verbal and non-verbal habits; and it helps to define power distance relationship of participants in any discourse or interaction.

Mills (2000, p. 1) views the notion of pragmatic politeness as something which occurs at a "discourse level, over stretches of talk and across communities of speakers and hearers." According to her, it is the community of practice which decides over whether a particular speech act is polite or not, and not the individual speaker or hearer. She notes that it is important to be aware of the fact "that there may be conflicts over the meaning of politeness" (p.1). In other words, the notion of politeness is a judgmental act based on societal and cultural norms which are highly flexible and therefore places politeness at a high risk of misunderstanding and misapprehension.

However, an important element in the process of politeness judgment is whether "an utterance is appropriate or not, either in relation to the perceived norms of the situation, the community of practice or the perceived norms of the society as a whole"(p. 4). Leech, however, notes that there are certain speech acts which are inherently impolite; as in when making offers (Mey, 2001, p. 80). Mey (2001) disagrees with Leech's assertion. According to him, "this view 
assumes politeness to be an abstract quality, residing in individual expressions, lexical items or morphemes, without regards for the particular circumstances that govern their use" (p. 80). He goes further to note that the notion of politeness is a complex one in the sense that the social status of the speaker and hearer contribute to whether the utterance is polite or not.

Every normal being possess 'face', that is self-esteem, public image or identity display by individuals, and everyone likes to protect his/her 'face'. Brown and Levinson (1987, p. 61) argue that "face is something that is emotionally invested, and that can be lost, maintained or enhanced, and must be constantly attended to in interaction." They observe that participants in every interaction often express their cooperation with other participants by respecting co-participants' self-esteem. The notion of 'face' is regarded as a desire and not as norms or values which members of a society subscribed to. They identify two components of 'face' - negative and positive 'face'. Negative face is 'the basic claim to territories, personal preserves, and rights to non-distraction i.e. to freedom of action and freedom from imposition". Positive face is "the positive consistent self-image, or "personality' (crucially including the desire that this self-image be appreciated and approved of) claimed by interactions". In other words, every adult or rational being wishes or desires to be "autonomous and not to infringe on the other person", and at the same time, "wishes or desires to be liked or appreciated." The former, being negative politeness, can be regarded as a case of formality and the latter, positive politeness, a case of friendliness.

Scollon and Scollon (2001, p. 46) on their part consider 'face' as "a paradoxical concept". They identify two aspects of 'face' - involvement (Brown \& Levinson's positive face) and independence (Brown and Levinson's negative face). Although the two paired linguists use different terms, their definitions are similar. Involvement refers to the aspect of face which has to do with a "person's right and need to be considered a normal contributing or supporting member of society"; (p. 46) while independence aspect of face "emphasize the individuality of the participants... their right not to be completely dominated by group or social valves, ... free from the imposition of others" (p. 47). Their preference for the terms 'involvement' and 'independence' stems from the fact that "positive politeness connotes good and negative politeness connotes bad" (p. 47). Scollon and Scollon state that "both aspects of 'face' must be projected simultaneously in any communication" (p. 48). On the contrary, Brown \& Levinson's projection of face negotiation during communication differs; one either uses positive or negative strategy. Scollon \& Scollon (2001) argue "the reason involvement and independence are in conflict is that emphasizing one of them risks a threat to the other" (p.48). Hence, speakers often select the right speech Style to indicate the level to which they are involving other participants (friendliness) and the level to which they grant other participants their independence (formality). 


\section{Legislative Discourse}

Legislative official interactions, especially bill debates, are most often argumentative in nature. Argument comes into place because during debates the legislators often express, defend and attack the views of others, especially those speakers who belong to the opposition parties. Legislative debates are not simple debates but are "confrontation[s] between political parties, between government and opposition, and parliament as an institution that does things also as an institution."(Van Dijk, 2004, p. 357).

As a highly guided and complex interaction, legislative discourse involves well knowledgeable participants whose utterances are characterized by evidence and facts. Van Dijk (2004) posits that legislators' knowledge is acquired partly through "common sense knowledge, personal experiences and observations, hearsay (everyday storytelling), the medial, the court, experts or scholarship" (p. 93). The ability to signal this evidence of knowledge helps, not only to give credence to the speakers' integrity, but also helps the legislators to be able to fully participate in various topics during the debates. Legislative discourse is complex partly because the participants, as well as other participants in any discourse "construct many different roles, and such roles may affect the production and comprehension of discourse." (p. 351). These various roles in parliamentary discourse would help to decipher the speaker meaning. Dijk identifies "three basic types of role that are contextually relevant in communicative event:

a. communicative role [writer/reader, speaker/listener],

b. interactional role [friend/enemy, opponent/proponent] and

c. social role [class, ethnicity, age, gender]" (p. 351).

In legislative discourse, these various roles are combined and "each role is differently affecting the discourse structure" (p. 351). The speeches of the legislators are utmost importance not only to legislators, but also to the people whom they represent and the entire country. Van Dijk (2004) posits that "the ultimate point of their speeches or questions is making or amending laws or discussing, amending and usually ratifying Bills (as proposed by the government)" (356). He further states that these speeches are used to perform other various political acts, such as:

a. Representing their constituents,

b. Governing the country,

c. Criticizing the government,

d. Engaging in opposition,

e. Implementing party programs,

f. Making policy. (p. 356) 
Similarly, apart from these typical political acts, legislators also engage in more general social acts of different types, such as:

a. Making decisions,

b. Promoting themselves,

c. Reproducing (anti)racism [tribalism],

d. Making money. (p. 356)

He argues that all these acts "may take place concurrently, and may be realized by a single discursive act..." (p. 356). He concluded that "for each discursive act, [legislators] are - or may be - aware of the significance or functionality of such acts and this awareness influences the properties of their speeches." Therefore, legislators' communicative behaviors are highly constrained not only by the structures of the House, but also by other sociocultural and political factors.

This paper examines how Nigerian senators, who are members of different political parties, are able to conduct effective legislative interaction and arrived at a collective political decision for the wellbeing of the country. The questions are: 1) whenever the senators oppose the views of fellow senators how do they indicate that it is not their wish to 'attack' the senator's face-want? and 2) what type of indices of politeness are often utilized by the senators during legislative discourse?

\section{Method}

The data for this study is taken from the Senate Hansards of Nigeria $6^{\text {th }}$ National Assembly which was inaugurated in 2007 and ended in 2011. Within this four years period, a large number of bills which are too numerous for this study were debated upon. For efficient management and thorough analysis, six bills were sampled from 2009 to 2010. Each year was clustered into three quarters and one bill was sampled from each unit. The structure and nature of the bill debate are consistent and similar and hence the sampled bills are true representation of the population of the study.

The politeness theory adapted in this study is Scollon and Scollon (2001) because this model deals with how participants from varied socio-cultural setting are able to negotiate individual 'face' want during discourse. This study population, the Nigeria Senate, is made up of members whose socio-cultural backgrounds are distinct and unique and hence it is a regarded as a multicultural discourse setting.

Scollon and Scollon's model which is concerned with intercultural discourse, emphasizes the fact that politeness is influenced by three social factors; namely, power, distance and weight of imposition which are existing among the participants in a discourse. They posit that participants in any discourse are 
usually conscious of the common ground (group membership) shared by the participants as well as the individuality (independence) of the participants.

Thus, politeness is seen by them as a coin with two sides, and each side of the coin is as important as the other. Hence the two sides must be balanced none should be over flogged at the expense of the other. In other words, in every discourse, participants display the needs to be connected with others, which can be regarded as friendliness (involvement). Participants also display the need to be unique and independent, this need can be regarded as formality (independent).

\section{Results}

Our data reveal that senators do not wish to 'attack' co-participants' face wants in the course of their contributions to on-going debate. Hence, whenever a senator's contribution opposes another senator's views or ideology, the speaker ensures that his utterance is 'courteous'. Thus, senators eschew the possibility of 'offending' or hurting the face-want of others through the appropriate choice of diction.

Senators' speeches are characterized by some indices of politeness which we have tagged 'politeness indicators'. Politeness indicators refer to linguistic terms which occur in speeches as tools or indices of politeness employed by speakers as a form of ease of seemed impoliteness. Speakers often use these politeness indicators to express their intention to maintain cordial relationship and to respect other participants in a communicative event. In this way, speakers are able to avoid conflict which, according to Lakoff (1973), is inherent in all human interchange (p. 34), thus they can achieve harmonious interaction.

In Nigeria Legislative Discourse, politeness indicators often used by various speakers to express social equilibrium as well as to maintain cordial interactions during bill debates are: address forms, first person plural pronoun - we, rhetorical (speech) politeness markers and ritualized utterances. Speakers almost always punctuate their contributions to debates with these politeness indicators as a means of maintaining harmonious atmosphere during debates, bearing in mind that debates take place within a conflict prone argumentative context.

\section{Address Form}

Address form as used in this study, refers to not only 'vocative', that is a direct reference to the addressee in the person of the Senator President, but also to 'designative', that is reference to a third person being mentioned in the speech the other senators who are indirect addressees. The choice of address form during interaction depends on the nature of the discourse, interlocutors' face wants, as well as the social status existing among the participants in the speech event. 
Agbara:

Politeness Indicators in Nigeria Legislative Discourse

In Nigeria Legislative Discourse, speakers employ different types of address forms in their speeches. Below are illustrations:

1. Also the sponsor of the Bill distinguished Senator XY states that...

(6 $6^{\text {th }}$ speaker: Arbitration Bill)

2. My distinguished Colleague, Senators KB, has raised the point...

( $2^{\text {nd }}$ speaker: Constitution Bill)

3. The Bill is well intended; Senator AB has come with it out of..

( $7^{\text {th }}$ speaker: Arbitration Bill)

4. The community where Senator NBA comes from is almost in extinction...

( ${ }^{\text {rd }}$ speaker: Petroleum Bill)

5. As my Colleague, Senator TS said and summarized by Senator VNE ....

(16 ${ }^{\text {th }}$ speaker: Petroleum Bill)

6. The Amendment Bill brought in by the distinguished Senator AK is a very good one.

( $9^{\text {th }}$ speaker: Evidence Bill)

7. ... they said they did not know anything about it, that I should ask Senator GB.

(12 ${ }^{\text {th }}$ speaker: Appropriation Bill)

In these samples, the address form often used as "designative" is the term 'Senator' plus the name of the senator being referred to. Sometimes, the adjective "distinguished" is affixed. This type of address form is very productive in legislative discourse. The pragmatic effect of this address form is the expression of respect for the independence face want (formality) of the participants in discourse.

However, sometimes speakers use in-group membership identity in their speeches. The pragmatic effect of this is to express the "togetherness" of the interlocutors through the use of the address form "Colleagues" or "distinguished colleagues" as illustrated in the following samples.

8. As my distinguished Colleague said...

$\ldots$ I rise to invite my distinguished Colleagues to totally ...

( $7^{\text {th }}$ speaker: Petroleum Bill)

9. ....all the contributions made so far by my Colleagues...

(10 $0^{\text {th }}$ speaker: Evidence Bill)

10. ....and also invite all my Colleagues to lend their voices...

( $2^{\text {nd }}$ speaker: Terrorism Bill)

11. I wish to urge my distinguished Colleagues...

(12 ${ }^{\text {th }}$ speaker: Terrorism Bill)

12. ...and I join my Colleagues in stating that...

(3 $3^{\text {rd }}$ speaker: Appropriation Bill) 
13. I am happy that many of my Colleagues have mentioned that ...

(14 ${ }^{\text {th }}$ speaker: Appropriation Bill)

14. Few of our Colleagues have been victims of conflicting judgments... I suggest that other areas which a number of my Colleagues have raised here should...

(19 $9^{\text {th }}$ speaker: Constitution Bill)

In these samples, the speakers employ "colleague" or "distinguished colleague" as address form. The use of "colleague" as an identity reference of the interlocutor being mentioned in the speeches of the speakers has the pragmatic effect of respecting the involvement face want (friendliness) of the participants being referred to.

Another type of address form used in the discourse, though not as productive as that of title plus name and in-group term, is ranking terms like "(Senate) Leader" "Deputy Senate President. Below are samples:

15. In fact, what the Senate Leader has explained in the Lead debate...

( $7^{\text {th }}$ speaker: Petroleum Bill)

16. The Leader talked about revising the oil benchmark...

(10 ${ }^{\text {th }}$ speaker: Appropriation Bill)

17. The Senate Leader has told us that...

(12 ${ }^{\text {th }}$ speaker: Appropriation Bill)

18. ... I support what the Deputy Senate President has submitted totally...

(13 ${ }^{\text {th }}$ speaker: Constitution Bill)

These ranking terms are used by the speakers to express the independence face want of the interlocutor being referred to. It is pertinent to note that speakers' utterances are directly addressed to the Presiding Senator while the other senators are addressed indirectly. That is the speeches of the senators are channeled through the presiding senator who acts as an intermediary to the other co-participating senators. As results of this, speakers often begin their speeches with the address from "Mr. President" which is a "vocative" directed to the Presiding Senator. Below are some examples:

19. Mr. President, I am quite aware of the noble intentions of this Amendment but ...

( $5^{\text {th }}$ Speaker: Arbitration Bill)

20. Mr. President, this is a Bill that came a bit late...

( $9^{\text {th }}$ speaker: Petroleum Bill)

21. Mr. President, what I want to add to it is that...

(11 ${ }^{\text {th }}$ speaker: Evidence Bill)

22. Mr. President, this is a Bill that requires the attention of every senator...

(1 $1^{\text {st }}$ speaker: Terrorism Bill) 
23. Mr. President, we are charged with the responsibility of making laws...

(11 ${ }^{\text {th }}$ speaker: Appropriation Bill)

24. Mr. President, I rise to lend my support to these Amendments...

(12 ${ }^{\text {th }}$ speaker: Constitution Bill).

Also, the Presiding Senator is sometimes addressed as 'Sir' as demonstrated in the following:

25. Sir, we have not yet come to the supplementary budget yet...

( $7^{\text {th }}$ speaker: Appropriation Bill)

26. Sir, we shall on no account touch allocation for road.

(12 ${ }^{\text {th }}$ speaker: Appropriation Bill)

27. With your kind permission, Sir, I would like to quote...

(15 ${ }^{\text {th }}$ speaker: Appropriation Bill)

28. It means, Sir, that we are not taking our oversight function properly.

(15 $5^{\text {th }}$ speaker: Appropriation Bill)

29. I have not Sir...

(14 ${ }^{\text {th }}$ speaker: Constitution Bill)

30. Protect me, Sir.

(Said by a speaker who has raised point of Order after $3^{\text {rd }}$ speaker: Constitution Bill, p. Ap. 72)

31. That is what we are Sir.

( $6^{\text {th }}$ speaker: Evidence Bill)

The use of 'Sir' as address form has the pragmatic effect of the fact that the Presiding Senator has a higher status above the speakers. It acknowledges the hierarchical status of the Presiding Senator and functions as a marker of formality.

The use of address forms is very productive in the discourse and the pragmatic effect of the various address forms is to denote and express respect as well as acknowledge both the involvement and independence face wants of interlocutors. Thus the speakers are not only formal but are also friendly in their utterances.

\section{The First Person Plural Pronoun}

The first person plural pronoun 'we' and its inflectional forms 'our' and 'us' abound in the speeches of the senators. This politeness indicator is used to express the 'inclusiveness' or 'togetherness' and solidarity of both the speakers and the addressees in the ongoing discourse. Below are samples:

32. We really need to look at this Bill again because despite the good intensions there are some problems.

(6 $6^{\text {th }}$ speaker: Arbitration Bill) 
33. We are looking at it from two directions.

( $4^{\text {th }}$ speaker: Arbitration Bill)

34. ...if we further stretch our arms to the same in the areas of gas, it would be like duplicate and doubling our opportunity, and our chances...

(6 $6^{\text {th }}$ speaker: Petroleum Bill)

35. If we want to do justice to the Evidence Act, we must, as a matter of urgency, as Senator AK as attempted to address this issue.

( $4^{\text {th }}$ speaker: Evidence Bill).

36. We must be very careful ...

(5 $5^{\text {th }}$ speaker: Terrorism Bill)

37. ... one of the thing we have to do would be to define within the context of our culture and the nature of our people what terrorism is.

(10 $10^{\text {th }}$ speaker Terrorism Bill)

38. ... so we are going to go 40 days and not less than 20 days and we will keep going ding dong.

( $8^{\text {th }}$ speaker: Appropriation Bill)

39. ... the proposal that we should take the date to do the election to Electoral Acts maybe, we need to have in the Constitution ...

(12 ${ }^{\text {th }}$ speaker: Constitution Bill)

As illustrated above, hardly would any senator speak without punctuating the speech with the first person plural pronoun. Thus, it is emphasizing the collective intentionality of the participants of the discourse. This politeness indicator has the pragmatic effect of denoting the unity and togetherness existing among the senators. It is the expression of togetherness which helps create conducive atmosphere for effective legislation. This politeness indicator acknowledges the involvement face want of the interlocutors in the speech event and serves as a marker of friendliness.

\section{Rhetorical (Speech) Politeness Markers}

Rhetorical (speech) politeness markers refer to the group of words used by interlocutors to reduce the weight of imposition on the listeners so as not to infringe or intrude on the listeners' privacy. Rhetorical (speech) politeness markers used as politeness indicator in discourse include, but not restricted to such phrases as "let me/us..., "allow me...," "I want to ...," "I enjoin...," "I would like...". Except "would" all others are lexical verbs functioning as speech act verbs used for suggesting politeness when making requests. Rhetorical (speech) politeness markers are employed by interlocutors in a discourse as a means of reducing the weight of imposition on the listeners, thereby respecting the listeners' face wants, and achieving harmonious interaction. Rhetorical (speech) politeness markers are often employed in conflict prone discourse characterized by verbal confrontation like debate as well as in formal and solemn occasions. 
In Nigeria Legislative Discourse, rhetorical (speech) politeness markers are very productive in the speeches of senators who try not to impose their point of views on other senators in order to create an atmosphere that is conducive for Bill debates. Below are samples of utterances containing rhetorical (speech) politeness markers:

40. Let me express my support for this very important Bill.

I would like to also address our minds to the rest cause of terrorism.

(6 $6^{\text {th }}$ speaker: Terrorism Bill)

41. If you permit me, I would read ...

( $9^{\text {th }}$ speaker: Terrorism Bill)

42. I would begin by condemning...

I want to also say that ...

$\left(11^{\text {th }}\right.$ speaker: Terrorism)

43. ... let me take off from where Senator AZ stopped.

I want to support this Bill with some reservations,

Let us look at the possibility of leaving those that in our Judgment require priority and pushing.

$\left(4^{\text {th }}\right.$ speaker: Appropriation Bill)

44. I would use this opportunity to appeal that this Senate be allowed to do its work ... we would see on the pages of newspapers that

( $2^{\text {nd }}$ speaker: Constitution Bill)

45. As a result I have my reservations. So permit me to take my seat.

(6 th $^{\text {th }}$ speaker: Petroleum Bill)

46. If I may have your permission let me just mention some of them that ...

(20 $0^{\text {th }}$ speaker: Petroleum Bill)

47. ... with your kind permission I read: ...

(Point of Order raised after the $19^{\text {th }}$ speaker's contribution Petroleum Bill)

48. Let us use this opportunity of this Amendment Bill to take a very comprehensive look...

( $3^{\text {rd }}$ speaker: Evidence Bill)

49. I want to also add that this Amendment should include electronic evidence or... I want to say that the issue of Law Reform Commission delaying the process of Amendment to this Bill is...

(10 $10^{\text {th }}$ speaker: Evidence Bill)

These samples demonstrate how speakers use rhetorical (speech) politeness markers like "let me/us..." "I want to ..." "I would..." and "you would". 'Would' is very productive because of the pragmatic implication of being tactful and polite. According to Leech and Svartvik (2001, p. 169 \& 179) both 'will' and 'would' are used to make requests and wishes. However, 'would' is more tentative and tactful than 'will'. This formulaic 'I would ...' has the pragmatic effect of making the utterances to which they are attached courteous and diplomatic 
(formal). The use of the performative verb 'permit' is not very productive in the data. Through the choice of these rhetorical (speech) politeness markers, the speakers are able to acknowledge the view points of the listeners so that the speakers' speeches do not seem as impositions on the listeners. This is a linguistic strategy of independence.

\section{Ritualized Utterances}

Ritualized utterances refer to group of legislative formulaic (conventionalized statements) used to express speaker's acknowledgement of the face want of other participants in the discourse. These ritualized utterances are series of regularly repeated statements by various speakers employed as a means of recommending the acceptance of the Bill being discussed. Below are illustrations:

50. ... I support this Bill and enjoin my Colleagues to do so...

(17 ${ }^{\text {th }}$ speaker: Terrorism Bill)

51. I urge all my Colleagues to please in our patriotic zeal, support this Bill because...

(11 ${ }^{\text {th }}$ speaker: Petroleum Bill)

52. ... I urge this Senate to see this Bill as a good one and a way out to ensure transparency in the industry...

( $5^{\text {th }}$ speaker: Petroleum Bill)

53. I urge my Colleagues to be digital compliant and support this Bill.

( $4^{\text {th }}$ speaker: Evidence Bill)

54. I would like to urge my Colleagues to support the proposed Amendment.

(16 ${ }^{\text {th }}$ speaker: Constitution Bill)

55. I, therefore, urge this distinguished body to look into this Bill and give it support.

( $1^{\text {st }}$ speaker: Arbitration Bill)

56. I urge my Colleagues to support it.

( $3^{\text {rd }}$ speaker: Appropriation Bill)

From these illustrations above, the recursive linguistic items in the ritualized utterances are "support" and "urge". The speakers use these utterances to appeal to the senators to support the Bill being discussed. Thus, the speakers' points of views are not imposed on the senators. The use of the verb "urge" has the pragmatic effect of acknowledging and respecting the listeners' independence face want; and the listeners are given the choice to accept or reject the speakers' points. However, when a senator does not support a bill or an issue, there is no ritualized formulaic. Such speakers are rather diplomatic not to 'injure' the other participants who support the bill or the issue. Lack of support is often presented in an inductive (indirect) manner as illustrated below: 
57. We have to look into this more closely, study it and come up with something that would be acceptable anywhere; otherwise we would be scaring off investors to the country.

( $2^{\text {nd }}$ speaker: Arbitration Bill)

58. Mr President, let me confess that my heart is with this bill but I am not very sure whether my head is with it.

( $7^{\text {th }}$ speaker: Arbitration Bill)

59. My President, this Bill seeks to monitor financial transaction .... The only problem I have here is that these are really not our prescriptions.

(15 ${ }^{\text {th }}$ speaker: Terrorism Bill)

60. I am not against the Senate passing this Bill but .... By passing this Bill, we are eventually handing this country over to imperialist world to control our financial transaction.

(18 ${ }^{\text {th }}$ speaker: Terrorism Bill)

\section{Conclusion}

The senators through their speeches during legislative debate (which is characterized by opposing views and thus conflict prone) are able to reduce or defuse the seemed conflicts during the discourse. This is made possible through appropriate choice of dictions which aid to calm the tension of opposition. The various sampled data have revealed that the inclinations of conflict in legislative discourse, and by extension, any verbal confrontation context, can be reduced through the use of politeness indicators like address forms, first person plural pronouns, rhetorical (speech) politeness markers and ritualized utterances.

In Nigeria legislative discourse address form (politeness indicator) is used both as vocative and designative as a form of expressing respect for the face want of the addressees. The use of first person plural pronoun as indices of politeness underscores to the togetherness (solidarity) of the senators and as sure the senators are able to put behind them the feeling of opposition. There is also the use of rhetorical (speech) politeness markers which are employed as means of reducing the weight of imposition on the addressees. And finally ritualized utterances (such as I support..., I urge...) are employed as means of expressing speakers' acknowledgement of the face want of co-participants in the debate.

The use of these politeness indicators aid speakers to minimize and mitigate impolite linguistic behaviors. Thereby promoting the appreciation and respect of the face wants of other interlocutors in the discourse and creating an atmosphere that is conducive for harmonious interactions in spite of the conflict prone environment which is characteristic of legislative discourse. 


\section{References}

Brown, P., \& Stephen, C. L. (1987). Politeness: Some Universal Language Usage. Cambridge: Cambridge University Press.

Grundy, P. (2000). Doing Pragmatics. London: Arnold Publishers.

Lakoff, R. (1973). Language in Context. Language Vol.48, (4), 907 - 927.

Levinson, S. C. (1983). Pragmatics. Cambridge: Cambridge University Press.

Leech, G. (1983). Principles of Pragmatics. London: Longman.

Leech, G., \& Jan, S. (2001). A Communication Grammar of English. 3rd ed. London: Longman.

Mey, J. L. (2001). Pragmatic: An Introduction. Oxford: Basil.

Mills, S. (2000). Rethinking Politeness, Impoliteness and Gender identity. Retrieved August, 12, 2014, from http://www.linguisticpolitenesseclipse.co.uk

Scollon, R., \& Suzanne, W. S. (2001). Intercultural Communication: A Discourse Approach. Oxford: Blackwell.

Nigeria Senate Standing Orders. (2007). Amended. $6^{\text {th }}$ National Assembly, Abuja: Senate of the Federal Republic of Nigeria. Print.

Van Dijk, T.A. (2004). Text and Context of Parliamentary Debates: Cross-Cultural Perspective on Parliamentary Discourse. P. Bayley (ed.) Philadelphia: John Benjamins Publishing Company.

Yule, G. (2008). The Study of Language. $3^{\text {rd }}$ ed. New Delhi: Cambridge. 